\title{
THE 1988 BRAZILIAN CONSTITUTION AND ITS COUNTRY PROJECT: IS THERE STILL ROOM TO DREAM?
}

\author{
LA CONSTITUCIÓN BRASILEÑNA DE 1988 Y SU PROYECTO DE PAÍS: \\ ¿AÚN HAY ESPACIO PARA LOS SUEÑOS?*
}

\section{Marcus FiRMinO SANTIAGO**}

RESUMEN: En 1988, Brasil promulgó su nueva Constitución, que representaba el acto final de la larga transición democrática iniciada una década antes. En ese momento, contrario a la tendencia dominante en el Occidente capitalista, se hizo un compromiso con el bienestar social, enfocándose en la acción estatal y en la expansión de la participación democrática como formas de superar una larga historia de desigualdad y exclusión. Las promesas constitucionales, sin embargo, no se han cumplido plenamente. El país enfrentó largos períodos de graves dificultades financieras que limitaron la capacidad de los gobiernos para actuar. $\mathrm{Al}$ mismo tiempo, las fuerzas conservadoras resistieron continuamente, buscando vaciar el proyecto estatal prometido en 1988. A pesar de las dificultades, la sociedad ha experimentado grandes avances, sin embargo, la ruptura soñada con una realidad de pobreza
ABSTRACT: In 1988, Brazil promulgated its new Constitution, which represented the final act of the long democratic transition begun a decade earlier. At that moment, contrary to the dominant trend in the capitalist West, a commitment was made to social well-being, focusing on state action and on the expansion of democratic participation as ways to overcome a long history of inequality and exclusion. The constitutional promises, however, have not been fully realized. The country faced long periods of severe financial difficulties that limited governments ability to act. At the same time, conservative forces resisted continuously, seeking to empty the state project promised in 1988. Despite the difficulties, society has experienced great advances, however, the dreamed break with a reality of poverty and exclusion did not happen. And today, faced with a scenario of global economic down-

* Recibido el 8 de mayo de 2020; aprobado el 18 noviembre de 2020.

** ORCID: 0000-0001-5200-4896. Postdoctorado en Derecho, Estado y Constitución. Doctorado en Derecho de lo Estado. Profesor del curso de grado en Derecho del Instituto Brasiliense de Direito Público (IDP). Abogado especializado en Derecho Constitucional. Correo electrónico: marcusfsantiago@gmail.com.

Boletín Mexicano de Derecho Comparado, nueva serie, año LIII, núm. 159, septiembre-diciembre de 2020, pp. 1207-1234.

Esta obra está bajo una Licencia Creative Commons Atribución-NoComercial-SinDerivar 4.0 Internacional, IIJ-UNAM. 
Esta revista forma parte del acervo de la Biblioteca Jurídica Virtual del Instituto de Investigaciones Jurídicas de la UNAM

y exclusión no sucedió. Y hoy, ante un escenario de recesión económica mundial y extrema fragilidad financiera del Estado, hay voces crecientes que defienden el abandono de los valores constitucionales, apostando en los mercados como una forma de superar las dificultades actuales.

Palabras clave: Constitución brasileña de 1988, Estado de bienestar, democracia, desigualdad, exclusión social. turn and extreme financial State fragility, there are growing voices that defend the abandonment of constitutional values, betting on markets as a way to overcome the current difficulties.

Keywords: 1988 brazilian Constitution, welfare state, democracy, inequality, social exclusion.

\begin{abstract}
SUMMARY: I. Introduction. II. On the eve of the Constituent Assembly, a shadowy scenario of misery and exclusion: inequality in debate. III. The dreams of an era. IV. The unique experience of a participative model: the 1987/88 Constituent Assembly as a field open to different political actors. V. The bet on the welfare state as a way to break a reality of exclusion and inequality. VI. Now comes the biggest challenge: how to make the constitutional model come true? VII. Conclusion.
\end{abstract}

\title{
I. INTRODUCTION
}

The last decade was marked by a strong economic downturn, reflecting the great crisis of 2008 that reached, in greater or lesser extent, the entire globe. More than a reduction in available wealth, the main and saddest feature of this period has been the continuous and sharp growth of social inequality, which became even more evident and dramatic with the Covid-19 epidemic that has plagued the world and affected the poorest in a particularly severe way. An increasing number of people are living in miserable conditions, without access to essential services and much more exposed to the new and deadly disease. At the same time, those who occupy the top of the economic pyramid continue to have secured their access to healthcare and work protected in their homes, while their wealth increases to levels still unknown.

In Brazil, the current social and economic situation is severe and reflects the difficulties experienced in other countries. Plunged into a persistent economic crisis, since 2015 the labor market has deteriorated, the average income is stagnant and the number of people living in poverty has increased. Several social indicators show that people's living conditions 
Esta revista forma parte del acervo de la Biblioteca Jurídica Virtual del Instituto de Investigaciones Jurídicas de la UNAM

are getting worse (Oxfam 2019). At the same time, the last government (2016-2018) and the current one (since 2019) have insisted on the adoption of neoliberal economic prescription, with its fiscal austerity policies aimed at reducing the size of the State, whose implementation has implied successive changes in the 1988 constitutional project.

The federal Constitution of 1988 represented a bet on the Welfare State as the way to overcome a persistent reality of poverty, inequality and exclusion that marked the country. And this occurred at a time when Brazil, like much of the capitalist world, was plunged into a severe economic crisis, undermined by a growing and uncontrollable public indebtedness. Then, against the northern hemisphere dominant neoliberal ideology, Brazilian society chose to prioritize the social problems that accumulated, realizing that there was no more room for a model that concentrated wealth and fostered social inequities.

The social welfare promised three decades ago, however, was never fully implemented. Brazil remains an extremely unequal and exclusionary society, where a small financial elite holds most of the wealth and the access to essential services is not for everyone. Its people badly need the state's distributive action to at least mitigate such disparities, however, the state's intervention capacity has been increasingly questioned and reduced. Attacks on the Constitution and its social project accumulate, making room for reforms aimed at deconstructing one of its structuring pillars: the universal social protection system (Carvalho 2018, chapters 3 and 4).

As a result of a historical process that cannot be forgotten or ignored, the 1988 Constitution paved the way for significant transformations in the Brazilians' lives and still has the potential to allow overcome the current moment of difficulty. Betting on the capacity of state action, based on the search for the common good and concerned with serious accumulated social deficits, was not a mistake. And the economic difficulties experienced by the country cannot be attributed to the constitutional social protection system.

The fact that today Brazil and much of the world are living even more difficult times than those experienced in the 1980s justifies seeking to understand the choices made at that moment, when the Welfare State was elected the best alternative to rescue huge accumulated social deficits. Thus, in a moment when the Constitution suffers so many and so strong 
Esta revista forma parte del acervo de la Biblioteca Jurídica Virtual del Instituto de Investigaciones Jurídicas de la UNAM

attacks, it is understood necessary to remember the context of its elaboration in order to highlight the importance of its transformative project.

The aim of this study is to rescue the debates that guided the National Constituent Assembly of 1987/88, in order to understand the reasons for betting on the State as an instrument to combat inequality and social exclusion, and the difficulties faced in the following years, which limited the implementation of the constitutional objectives. It seeks to demonstrate that today's criticisms against the Constitution are not justified by a socalled failure of its project but represents the continuation of the enormous resistance that has always been opposed to it.

\section{On THE Eve OF THE CONSTITUENT Assembly, A SHADOWY SCENARIO OF MISERY AND EXCLUSION: INEQUALITY IN DEBATE}

To understand the constitutional model that emerged in 1988, it is necessary to remember the political and social framework experienced in Brazil of the 1980s, a period of severe economic crisis, still due to oil shocks in the previous decade, and serious social instabilities. In this complex context, the long democratic transition that began in 1978 was concluded and the drafting of the new constitutional text was finally set-in motion. Contrary to what was happening in developed countries, the State was invested as a transforming agent, in a broad and comprehensive protective project that should definitely insert Brazil into the social welfare paradigm. The time has come to end the human deficits and the brutal inequality that plagued the country for so long.

It was a tortuous trajectory, after which not everything that was desired was achieved, but that represented a moment of surprising boldness and democratic glow that allowed the construction of the political and normative bases to achieve important advances in reduction of inequality and access to essential goods and services.

Although there was no talk of globalization at that time, there was already a strong interdependence between world economies, so that the retraction cycles affected everyone to some degree. In the case of the oil crises of the 1970s, contagion was intense, since it comprised the basic energy matrix, so that the channeling of resources for its acquisition drained the main sources of public and private financing. This was particularly 
Esta revista forma parte del acervo de la Biblioteca Jurídica Virtual del Instituto de Investigaciones Jurídicas de la UNAM

serious because it occurred at a time when state indebtedness was quite high, with great dependence on constant capital flows. The international liquidity crisis led to the explosion of Brazilian external debt, with the consequent budget bottleneck of the State (Albuquerque 1987, 99).

The social impacts were direct and particularly aggravated due to the exclusionary development model adopted by military governments, which left a legacy of unequal economic growth, from which selective benefits resulted and which generated enormous social distortions. Brazilian people lived in Belíndia, expression coined by the economist Edmar Bacha (1974) to illustrate the coexistence of groups that flaunted a standard of living similar to that that existing in Belgium with others, who only knew levels of misery like those then present in India. ${ }^{1}$

In fact, in different aspects there were significant advances, such as increasing urbanization, large investments in infrastructure, expansion of the industrial park, large-scale production of transport and communication equipment. Brazil reached the end of the 1970s as an economy "(...) modern, diversified and integrated into the international financial economic system" (Albuquerque 1987, 97) The then eighth biggest economy in the capitalist world, however, remained an underdeveloped and deeply unequal country. It is interesting the synthesis of Marcos Albuquerque (1987, 97):

The permanent misery present in absolute terms, becoming even more revolting in comparative terms; slums and tenements proliferate in all urban centers; health and education remain a privilege of difficult, if not impossible, access to much of the marginalized population of modern Brazil. Access to work, when existing, is often more exhausting than productive activity itself. Safety, hygiene and leisure mean nothing but distant and unattainable chimeras.

As Bresser-Pereira explains, the economic and political pact signed in the 1960s and 70s between financial elites and government was supported by authoritarian roots and aimed the radical exclusion of workers

1 The article, published in 1974, is an allegory that denounces the brutal inequality of income and the falsehood of the criteria used to measure the expansion of national GDP, which masked the constant appropriation of wealth by the financial elite, in a model of excluding growth. 
Esta revista forma parte del acervo de la Biblioteca Jurídica Virtual del Instituto de Investigaciones Jurídicas de la UNAM

and the establishment of a structure that would speed up the cumulative process, especially at the financial and industrial sectors, the most modern face of the economy (Bresser-Pereira 1988, 22). Brazilian economic development was characterized, therefore, by a destructive elitism, which promoted a demeaning degree of accumulation and concentration of wealth and, consequently, fed a mass of helpless. Democratic openness allowed the veil that covered this "(...) economic, geographical, social and cultural dualism" to be removed (Albuquerque 1987, 97).

The authoritarianism prevailing since 1964 sought for a long time to empty the capacity of articulation around social causes, but its inability to react to the economic collapse that, even with some delay, ended up landing in Brazil contributed to the resumption of a debate that had remained suffocated, but had not been annihilated. The bourgeoisie, little by little, was abandoning the military regime to the extent that it was no longer able to serve its interests and ensure economic benefits (BresserPereira 1988, 26-27). This group did not reject its tradition of political and social conservatism and the dependence on state stimulus but began to admit the need for a moderate redistribution of income, bargaining chip that seemed sufficient to contain the growing mobilization and radicalism of workers (Bresser-Pereira 1988, 23).

The pact between capital and labor helped to maintain the linearity of the political opening process, avoiding the worsening of conflicts while signaling to the military the imminent exhaustion of their authority. On the other hand, the growing social action, spread by different layers of the population, could not simply be silenced. After all, the current social reality data were shocking and has been compiled by Wanderley Guilherme dos Santos in a relevant study published in 1986.

At the time, the Brazilian population was 135 million inhabitants, of which about $27 \%$ (of those over 5 years old) were illiterate. Looking at regional extremes, while in the South and Southeast the rate was $18 \%$, in the Northeast the percentage of illiterates reached $47 \%$, evidencing the severity of asymmetries. Regarding the income earned, about 34\% of the Economically Active Population (EAP) lived with up to one minimum wage (in the Northeast, $51 \%$; in the Southeast, 22\%). Life expectancy reached 67 years in the Southern Region and was no more than 51 in the Northeast. Less than half of the EAP contributed to the social security system, which was then restricted to regulated professional categories 
Esta revista forma parte del acervo de la Biblioteca Jurídica Virtual del Instituto de Investigaciones Jurídicas de la UNAM

(Santos 1986, 365-393). It was a dramatic reality, of widespread exclusion and low expectations of social progress. In the author's synthesis (Santos 1986, 370):

Seen from a distance or, less metaphorically, from a very aggregate perspective, the nation's social state reveals deficiencies that are in themselves quite significant: illiteracy levels, distortions in employment opportunities, income levels, housing conditions, life expectancy, magnitude and causes of child mortality, coverage of labor legislation and the social security system-all of these indicators present insufficient or excessive rates, as the case.

Waldir Pires $(1989,252)$ is another author who lived those years and recorded his impressions, which complement the data collected by Wanderley Guilherme dos Santos:

The conservative modernization that led Brazil to the 8th world economic power, did it maintain 70 million inhabitants in a state of poverty, whether in the urban or rural area, without civil rights, without basic social services, without the necessary food to its biological condition, in a hunger process endemic and historic. They are the slums men, the poor workers, the malnourished, the people scourged by droughts, the migrants, finally, the huge portion of the society's builders.

Exclusion was not just economic. Many people have been leaved out from the decision-making process, they had no voice. "The social segments that make up the workforce did not participate in the decisions that led 51 million Brazilians, members of the economically occupied population, to focus on the lowest wage levels (...)", summarizes Waldir Pires (1989, 252).

On the eve of the Constituent Assembly, almost everyone knew that it was not enough only pursuing economic development. The time had come to recognize and face social conflicts, to untie the "knots of economic contradictions" (Albuquerque 1987, 97) There was an increasing and widespread pressure among different groups that claimed for the redemption of the social and political debt that had accumulated over the years. As Régis de Castro Andrade then synthesized: “(...) it is about the difficulty of leading a country of dynamic and wild capitalism, with huge debts and inhabited by a miserable population, in its majorityo" $(1988,13)$. 
Esta revista forma parte del acervo de la Biblioteca Jurídica Virtual del Instituto de Investigaciones Jurídicas de la UNAM

\section{THE DREAMS OF AN ERA}

The main demands present in the Constituent Assembly can be articulated in two axes: widespread inequality and misery, on the one hand, and democratic participation, on the other.

The demand for political participation was rising from the end of the 1970s, in the wake of the democratic openness and amnesty that allowed the return of historical opposition leaders, and exploded in 1984, in the Diretas fá campaign, "(...) largest mass movement of the second half of the 20th century in Brazil and [which] activated society" (Coelho 2009, 23) around the struggle for the reestablishment of direct elections for President. The issue of the social deficit was for a long time masked by the country's economic growth, which generated the illusion that, at some point, a minimally equitable earnings distribution would happen. The certainty about the exhaustion of this model brought with it the awareness of the enormous lack of social services and mechanisms capable to minimizing the economic inequality impacts (Andrade 1988, 13).

The urgency of the social issue was presented in a study prepared by the Planning Secretariat (Seplan), under president José Sarney government, published on May 8, 1985 and transcribed in the work of Ivanete Boschetti (2006, 102):

The Brazilian economy has experienced remarkable rates of economic growth in recent decades. Nevertheless, [nor] the high levels of social and regional inequality, nor pockets of poverty in the country, have been eliminated. As Brazilian society opens up to democratic experience, it is no longer possible to continue postponing the confrontation of social problems. The consolidation of the democratic regime requires the expansion of the foundations of social consensus, i. e. the substantive democratization of society, which requires the elimination of inequalities and the extension of fundamental social rights to the entire population.

It is possible to note in this report the connection between the two axes described above. It was a fact that the growth of previous years had not been reversed in benefits shared by the majority of the population, remaining alive social and regional asymmetries. According to the renewing spirit that guided Brazil's transformation projects, the fight against inequality should walk arm-in-arm with the expansion of democracy. It 
Esta revista forma parte del acervo de la Biblioteca Jurídica Virtual del Instituto de Investigaciones Jurídicas de la UNAM

would not be enough to formally affirm political rights or adopt palliative measures to combat poverty. The time has come to recognize the interrelationship between political, economic and social deficits and to ensure that historically excluded groups would have a voice, would have their claims heard.

A similar point of view was present at Sarney government's 1st National Development Plan, presented in 1985. This is a preview of several of the vectors that would guide the Constituent (Boschetti 2006, 106):

Alongside the more political principles related to administrative and public management reform, such as the decentralization of actions and the participation and control of society, it was possible to identify the principles that, from then on, should reorient the social policies. The most recurrent were the universalization of health, the selectivity of social security benefits, the decentralization of social policy management and the integration and rationalization of various care programs that, to date, were diffuse and sprayed.

On the agenda were the administrative reform of the State, which aimed at decentralization, with the consequent strengthening of the subnational entities and, mainly, of the social participation mechanisms. After an era of closure around successive authoritarian governments, social protagonism should be restored, always seeking the inclusion of vast groups historically excluded.

As for the social policies listed, there is an approximation with the paradigm of universal welfare State, according to Gosta Esping-Andersen's concept (1991, 109-110). ${ }^{2}$ A broad base of protective mechanisms, with open access, as a way to incorporate vulnerable groups and, thus, form a minimal civilizing floor. The health / social security / assistance tripod was already enunciated as a structuring element of the new social policy that should guide the State.

2 As the author explains, the universal (or social democratic) model “(...) translates into a mixture of highly de-commodifying and universalist programs that, nevertheless, correspond to differentiated expectations. Thus, manual workers come to enjoy rights identical to that of white-collar employees or civil servants; all layers are incorporated into a universal insurance system, but even so the benefits are graduated according to the usual gains. This model excludes the market (...) Everyone benefits; all are dependent; and supposedly everyone will feel compelled to pay" (Esping-Andersen 1991, 109-110). 
Esta revista forma parte del acervo de la Biblioteca Jurídica Virtual del Instituto de Investigaciones Jurídicas de la UNAM

In the first half of the 1980s, studies on the Brazilian reality gained great impulse. It was necessary to know and measure the social deficit, understand its causes and design feasible solutions. Inside and outside the government gathered experts, workers and ordinary people who suffered with the hardships of inefficient or non-existent public services. More than drawing theoretical frameworks necessary to systematize the various problems, such studies represented a moment of expressive social participation. They were not government technicians looking, from a distant and aseptic position, to the population; organized segments of society were assuming a protagonism that had been forgotten - or suffocated - until then. ${ }^{3}$

The broad debate on inequality and its causes that preceded the Constituent Assembly contributed to stimulate different groups, showing them that it would be possible to claim gains, whether of an individual or collective nature. The field was open to dream of a Constitution - and a country - that looked at the poorest and most vulnerable, that cared about minorities and gave them voice and rights. The constituent moment of 1987/88 was really unique in Brazilian institutional history. ${ }^{4}$

\section{THE UNIQUE EXPERIENCE OF A PARTICIPATIVE MODEL: THE 1987/88 CONSTITUENT ASSEMBLY AS A FIELD OPEN TO DIFFERENT POLITICAL ACTORS}

The constituent cycle, underway since the late 1970s, finally entered its reconstruction phase. The whole debate on Brazil's problems that had in-

3 In the words of Ivanete Boschetti: "Such researchs (...) were much more than the simple 'scientific' finding and systematization of the country's economic and social situation. What was really at stake was the participation of society in the elaboration of concrete propositions in the field of social policies" (2006, 103).

4 In the opposite pole were placed authors such as Bresser-Pereira, stating that social movements had, in fact, a marginal role in the redesign of the Brazilian State, with the financial elites leading the way: "This growing participation of urban social movements led, however, some analysts to propose the idea that the redemocratization process would have popular movements as its fundamental basis. It is, of course, a misunderstanding. In fact, the participation of these popular movements in favor of democratization only occurred indirectly, especially in elections". It should be noted that the author wrote this text in late 1983. The following years, especially the constituent period, brought data that show the mistake of his analysis (Bresser-Pereira 1988, 28). 
Esta revista forma parte del acervo de la Biblioteca Jurídica Virtual del Instituto de Investigaciones Jurídicas de la UNAM

creased during the period of democratic opening had made clear the need to refound the State on new bases. It would not be enough to review the current Constitution, a proposal suggested by some. The time has come to seek something new, based on fundamental rules that would give life to a new law system "(...) informed by the principle of social justice, replacing the authoritarian system that had been governing us for about twenty years" (Silva 2013, xxii). As José Afonso da Silva, an internal observer of that moment, recalls, the spirit of the people had already been awakened, "(...) that transmutes in social will, which gives integration to the political community (...)" allowing it to determine its way of existence (2013, xx).

José Geraldo de Souza Júnior, also an internal observer, found in 1987 that the constituent debate had opened wide possibilities for the reorganization of social forces that were emancipating, acquiring life and voice in a separate way from the traditional schemes of power. Despite the care that the dominant groups had over the opening period, taking care to ensure control of the entire process, a new dimension of citizenship was present and in movement. As the author says (Souza Junior 1987a, 10): "Indeed, the recent experience of the struggle for the construction of citizenship has flowed into the constituent process, bringing to the debate, which it provided, clear and specific demands that aspire to become basic rights and freedoms, at the same time as instruments of organization, representation and active participation in the economic-social and political structure of society".

More than two decades later, this sensation remained alive in people who lived the constituent moment. João Gilberto Lucas Coelho, in a study organized by the Chamber of Deputies on the occasion of the 20th anniversary of the constitutional promulgation, gave special emphasis to the mobilization of social organizations of various natures such as rural workers, indigenous people and homeless people, many born clandestinely, along with traditional actors such as political parties and entities such as OAB (Brazilian Bar Association) and ABI (Brazilian Press Association), in a rich and plural amalgam (Coelho 2009, 22).

Segments without any organizational tradition emerged, clustered around the common purpose of being recognized as part of a single, open and inclusive society. Landless, homeless, street boys and girls, domestic workers, indigenous and retirees are some examples of groups that come to light, revealing their existence and their ills. "These movements erupted 
Esta revista forma parte del acervo de la Biblioteca Jurídica Virtual del Instituto de Investigaciones Jurídicas de la UNAM

in the Constituent Assembly and there found their opportunity for participation and political expression, overcoming discouragement or disbelief and causing an activating effect on society" (Coelho 2009, 30).

Unlike the traditional scenario, the Assembly would not be occupied only by the elites, engaged in maintaining their privileges. Conservative forces, which have always dominated governments of different party orientations, had to live with groups from the bottom of the economic pyramid that permanently occupied the National Congress halls, people of whose existence possibly many had never heard of. It was natural, therefore, the pressure for the Constituent Assembly to adopt an effectively participatory procedural model, what happened through different paths, such as the public hearings held in the first months of work and the Popular Amendments, whose insertion in the constitutional project was compulsory. ${ }^{5}$

It is clear that such mobilization would find resistance in conservative segments that were opposed to the intended popular empowerment. A secular authoritarian tradition is not broken with just a few movements. José Geraldo de Souza Júnior perceived — and feared — this influx: "The alternative of a popular power, capable of sketching an organization project in the Constituent to articulate the appearance of emerging social forces (...) bumped into its Gibraltar" (Souza Junior 1987b, 25).

The challenge was to keep open the narrow gap that at all times threatened to close. Progressive forces believed they were able to supplant the dominant political model, establishing a new order of values connected with the growing social demands. The new ideological spaces that had formed until then, however, did not seem able to generalize and dominate the field of the Constituent procedural debate (Souza Junior 1987b, 25). Even so, the level of participatory openness achieved surprised even a relatively skeptical observer, as the one studied here.

5 The National Constituent Assembly Rules of Procedure provided for direct popular participation in the debates of the thematic subcommittees, responsible for preparing the project chapters, and allowed the presentation of Popular Amendments, subscribed by at least 30,000 people and 03 representative entities. These were compulsorily included in the project and could only be suppressed or altered by the vote of the absolute majority of the constituents. 122 amendments were presented, and more than 200 public hearings were held. The participation in these meetings was so massive that it was not possible to count the presence of all (Backes, Azevedo, Araújo 2009, 15) 
Esta revista forma parte del acervo de la Biblioteca Jurídica Virtual del Instituto de Investigaciones Jurídicas de la UNAM

On the other hand, there were serious doubts if the demands formulated would, in the end of the process, be incorporated into the constitutional text (Souza Junior 1987a, 10). After all, what was sought was a Constitution that would confront the liberal order prevailing in the 1980s capitalism, a time when the response to the current fiscal crisis demonized models of social welfare, betting on the free market. This in a country whose decision-making process has always been dominated by a financial elite aligned with hegemonic models from the northern hemisphere.

Although the majority of the parliamentarians who made up the Constituent Assembly could be classified as conservative, this group was unable to articulate itself around a common project, revealing the fragility of the bonds that united them (Silva 2013, xxiii). And so, at the end, contrary to the neoliberal order present in the capitalist developed world, the State was chosen as the protagonist of economic and social development. The new Constitution incorporated principles of universal social protection, expanded the list of rights and insertion mechanisms aimed at vulnerable groups, brought new models of participation in the form of councils composed by the civil society, innovated with the popular legislative initiative. ${ }^{6}$ In short, at the same time that "(...) the welfare State was criticized and eroded by financial capitalism in the developed world, Brazil belatedly tried to build a social protection system inspired by some of the values of these regimes (...)" (Calixtre and Fagnani 2018, 327-328). ${ }^{7}$

6 The following rules are examples of the mentioned achievements: article $61, \S 2$. Conditions for the proposition of popular initiative bills; article 196. Healthcare as a fundamental right with universal access; article 201. Universalization of Social Security. Highlight for $\S 12$, which provides for a special system for low-income workers and domestic workers without income; article 203. Expands and institutionalizes social assistance, which is no longer charitable in nature; article 205. Social participation in the management of educational policies; article. 216-A. Joint management of policies aimed at promoting and protecting culture.

7 The authors add: "Thus, it was only in 1988 that Brazil incorporated some lines of the paradigm deepened by many central capitalist countries from the middle of the last century. However, when it did, that paradigm was already contrary to the movement of capitalism under the domination of finances and the hegemony of neoliberal doctrine on a global scale" (Calixtre, Fagnani 2018, 327-328). 
Esta revista forma parte del acervo de la Biblioteca Jurídica Virtual del Instituto de Investigaciones Jurídicas de la UNAM

\section{THE BET ON THE WELFARE STATE AS A WAY TO BREAK A REALITY OF EXCLUSION AND INEQUALITY}

After two decades of an economically ambiguous authoritarianism, but little concerned about a comprehensive social well-being, the country was anxious to retake the trajectory timidly begun with the 1946 Constitution and abruptly interrupted with the 1964 military coup. The State project designed in the Constituent was based on three vectors, identified by André Calixtre and Eduardo Fagnani: "(...) the restoration of the democratic state of law; the construction of a social protection system; and the conception of a macroeconomic strategy directed to growth with income distribution" $(2018,335)$.

As previously seen, the concentrating economic model needed to be changed, in the search for an inclusive development that would allow groups historically removed from the social structure to find their place. It was not enough, however, to bet on the redesign of the macroeconomic matrix and to complacently expect its effects to appear. An immediate, comprehensive and incisive action was essential, and the Constitution imposed this commitment on the brazilian State. And finally, the struggle for recognition could not fall into the void in the post-constituent period, after all, it had been the cause of all the transformation that had already operated in the country and which promised to produce even more. Democracy should be one of the structuring pillars, establishing a participatory and inclusive model.

The choice for social well-being meant giving the State the task of intervening directly in the causes of inequality, implementing a set of social policies, grounded on a coordinated system of taxation and spending, aimed at correcting existing imbalances and, thus, promoting inclusive development. The Constitution laid the foundation for the de-commodification of life and social relations, that is, to "(...) remove from the market competition the social needs deemed relevant, de-commodificating social reproduction, such as income guarantee programs and universal health and education systems" (Calixtre and Fagnani 2018, 328-329). ${ }^{8}$

8 The authors use the concept supported by Gosta Esping-Andersen of de-commodification, mentioned above, to explain one of the main commitments of a universal welfare State. 
Esta revista forma parte del acervo de la Biblioteca Jurídica Virtual del Instituto de Investigaciones Jurídicas de la UNAM

And so, the commitment to social transformation was imposed on ideological divergences, on the weight of financial interests and on the pressure from conservative forces, facing institutional structures that were not deconstructed in the democratic transition. Several compromise solutions were presented. After all, writing a Constitution demands that different world views, conflicting values, divergences and ill-resolved grudges be composed. A task that becomes even more difficult to be done "(...) in a time of transition, in which institutions and structures of the past and the impetus for change and disordered expectations still converge (...)" (Coelho 2009, 28).

It was a process of reciprocal concessions, throughout which several arm falls were fought. What would be reputed normal in any consolidated democracy, caused surprise in a Brazil unaccustomed to plural public debates. Conservative groups tried to use less republican strategies to impose their wills, there was a serious debate about regimental rules that could have led to the complete dismantling of the original project, ${ }^{9}$ but, in the end, that was promulgated a Constitution preponderantly committed to overcoming social ills, offering the necessary conditions for the construction of a more fair State. ${ }^{10}$

According to José Afonso da Silva, the 1988 Constitution is the result of a participatory and plural process (2013, xxvi):

The 1988 Constitution (...) emanated from a procedure with a lot of popular participation. It was made a Constitution that broke off with the past. From a slow, controversial formation, often tortuous, because a work of much popular participation, of the contradictions of Brazilian society and many negotiations resulted in a reasonably advanced Constitution, with innovations of

9 Throughout the work of the Constituent Assembly, a group was formed composed of center and right-wing parliamentarians aligned with the then President of the Republic. In exchange for positions and other benefits, they sought to change the procedure for approving amendments to the draft constitution in order to meet the interests of the Executive branch, occupied by a President strongly aligned with conservative forces, of which he was a part.

10 Details of the constituent process can be found in some of the referred studies, such as: Backes, Azevedo, Araújo 2009; Bastos; Costa 1987; and Vieira 2013. Extensive material for documentary research is also available on the Chamber of Deputies website: https:// wrww2.camara.leg.br/atividade-legislativa/legislacao/Constituicoes_Brasileiras/constituicao-cidada. 
Esta revista forma parte del acervo de la Biblioteca Jurídica Virtual del Instituto de Investigaciones Jurídicas de la UNAM

relevant importance for the Brazilian constitutionalism, a document of great importance for the constitutionalism in general (...)

Despite the disagreements, the mistrust with which observers of the time watched the constituent process and the Brazilian conservative tradition, the "great national agreement" (Boschetti 2006, 144) happened and a universal social security (articles 196, 201 and 203), rights for indigenous peoples (article 231), a differentiated look for women, the elderly, children and families emerged of it (articles 226 to 230). The environment gained space (article 225), the economic order was maintained under the tutelage and conduct of the State (article 170), the primacy of the work got affirmed, as well as the centrality of the human person (article 1st).

The constitutional lawmakers were not naïve to believe that all this would become an immediately reality at no cost. The State model outlined, interventionist and socially compromised, demands additional resources for the services' defrayal, most of which universal, under penalty of remaining limited to specific population segments and, consequently, losing their integrative character. After all, "(...) normative promises are one thing, reality is another" (Silva 2013, xxvi) On the contrary, experience warned of the risk of constitutional promises fall into the void, leading the entire national reconstruction project to the abyss. The fiscal structure needed to be rethought in order to ensure resources for the social policies that the country so badly needed. The social security costing model illustrates the path taken, based on the premise of broad social solidarity, with its redistributive mechanisms inspired by Keynes' lessons (Afonso 2018).

However, not everything went as expected. The pressure of financial elites led to a strongly regressive taxation system, which preserved the benefits of large capital. In Bresser-Pereira's reading (2012, x), "The businessmen participating in the pact did not agree to progressive taxes, but accepted increased social spending". The conceived tax system, with a regressive matrix, created a paradox, because the increase in revenue derives, in its largest portion, from a tax effort incident on the poorest, exactly those who should be protected (Kerstenetzky 2017, 25). The universalist claim was contained by a state financing model that was not suited to budgetary needs. All the constituents' creativity was restricted by objective 
Esta revista forma parte del acervo de la Biblioteca Jurídica Virtual del Instituto de Investigaciones Jurídicas de la UNAM

limits. It became commonplace to repeat the catchphrase: "the Constitution does not fit in the budget"...

\section{NOW GOMES THE BIGGEST GHALLENGE: HOW TO MAKE THE CONSTITUTIONAL MODEL COME TRUE?}

The country then entered a stage of frustrating expectation. After all, implementing the Constitution required a broad set of actions that should promote a real revolution in some ambits, such as public health. The necessary expansion of spending on education, social security, environment or housing simply had no room to happen. This was specially serious at a time when a succession of unsuccessful economic stabilization plans widened the financial constraints resulting from a prolonged period of economic stagnation, accompanied by a suffocating external debt and persistent and uncontrollable inflation that, between 1988 and 1991, marked the annual average of 1,177\% (Versignassi 2015, 237). And so, quickly, the debate shifted to practical and immediate issues, leaving aside the great and effervescent themes that boosted the Constituent Assembly (Nassar 2013, 32).

Only in the second half of the 1990s, thanks to the success of the Plano Real, a program that allowed inflationary control and financial and fiscal stabilization, "(...) the implementation of social rights and the social transformation goals have effectively returned to the agenda" (Nassar 2013, 34). Finally, social concerns found space again on the agenda and there was a resumption, albeit to a reduced degree, of the mobilization of different agents with the aim of demand from the government an effective commitment to the constitutional project (Lunardi and Dimoulis 2013, 62).

However, the same government that made room to implement the Constitution incorporated neoliberal ideology into its macroeconomic matrix. Consequently, given the incompatibility between the constitutional model and the liberalizing doctrine, “(...) Brazilian social protection began to live the tensions between antagonistic paradigms (Minimum State versus Social State)" (Calixtre and Fagnani 2018, 331). The conflict between Law and Economy overflowed from 1995 to 2002, giving rise to several measures contrary to the objectives originally outlined in the Constitution. 
Esta revista forma parte del acervo de la Biblioteca Jurídica Virtual del Instituto de Investigaciones Jurídicas de la UNAM

The reaction strategy adopted became clear. At first, accept the sovereign decision contrary to the economic power holders' interests, and, as soon as the popular mobilization dispersed, begin to work for its reform. In this way, "(...) the economic power tries, through ordinary actions favorable to its interest, to reform the sovereign political decision, changing the social and historical context so that the people change their sovereign decision, or even by removing [its] effectiveness (...)" (Menezes, 2014, 127) The main form of constitutional emptying was the abandonment of universal actions, prioritizing a selective system of social protection. "The centrality of macroeconomic adjustment and liberal state reform required that the focus on 'the poor' be the only possible social policy for Brazil" (Calixtre and Fagnani 2018, 332), a model that reflected the option for a minimum state.

Several measures were adopted between 1995 and 2002, in a kind of constitutional counter-reform. The Constitutional Emergency Fund (later replaced by the Untying of Union Revenues, or in Portuguese, Desvinculação de Receitas da União - DRU-) allowed important sources of financing for social policies to be diverted to other areas, such as payment of public servants or state debt's interest. The access to social security was hampered, which mainly affected people who were historically already excluded, such as rural workers; labor rights began to be flexibilized; important areas such as housing, sanitation, public transport and water and electricity distribution have been privatized, leaving it up to the market to decide social priorities (Calixtre and Fagnani 2018, 331-332).

In an article published in 1998, Dalmo Dallari denounced that: "Brazil only has Constitution and democracy when it does not disturb the government's accounts or the interests of the President of the Republic" (Dallari 1998) He criticized, then, the strength of the financial market, which would dictate the government's priorities and actions, in a movement of complete denial of the democratic paradigm outlined in the Constitution.

Then, between 2003 and 2014, the country experienced a new partypolitical cycle, reasonably identified with social values. In this period, the reformist fury was slowed and, finally, what remained of the constitutional project began to be put into practice. However, this occurred amid contradictions, making liberal and developmental agendas to coexist in a decade marked by paradoxes. 
Esta revista forma parte del acervo de la Biblioteca Jurídica Virtual del Instituto de Investigaciones Jurídicas de la UNAM

The economic stabilization achieved in the previous years allowed a significant increase in social spending, accompanied by policies for the recovery of the labor market, appreciation of the minimum wage, potentiation of the redistributive effects of social security and concrete measures to combat poverty, as the successful Bolsa Família Program, which guaranteed a minimum income for millions of families (Mattos and Nascimento, 2019). It was a virtuous moment in terms of growth of the GDP and the per capita income, with reasonable redistribution of wealth, which was made possible mainly by the role assumed by the State in the form of a strong increase in public investments (Carvalho 2018, 27-32). On the other hand, the liberal measures adopted previously were maintained and some others came, such as the Constitutional Amendment 40/2003, that made room to substantially reduce the regulation of the financial system. In the synthesis of Calixtre and Fagnani $(2018,333)$ :

Despite the generation of jobs and the real recovery of the minimum wage, the tensions between the paradigms of the minimum state and the welfare state, present since 1990, have remained fierce, as the increase of labor incomes has led to the displacement of the functional distribution of income, inflating the distributive conflict beyond the low resilience that Brazilian society, especially the owners of capital, have to allow and live with structural transformations.

Despite the clashes and tensions still present and that certainly limited the possibilities of social reality transformation, it is a fact that it was an important period of change in the State orientation, which finally began to move, even with stumbles and indecisions, in the direction conceived in 1988. Célia Kerstenetzky $(2012,161)$ attributes especially to the expansion of democratic action - remember, one of the vectors pursued in the Constituent Assembly - the social advances that finally began to come with greater intensity. A mobilization that led to the election of governments committed to redistributive social policies and allowed the implementation of a repressed agenda, proof that the clash between progressive and conservative forces was not resolved in the Constituent Assembly.

In the author's reading, more than a normative framework, the Constitution brought a set of commitments and a constant call to social action, of which it was a direct result, exercising decisive weight in order 
Esta revista forma parte del acervo de la Biblioteca Jurídica Virtual del Instituto de Investigaciones Jurídicas de la UNAM

to operate the significant reduction of inequality experienced in the first decade of the 2000s: “(...) the 1988 Constitution established the structural vectors to reduce inequality in Brazil. It can be speculated that the impacts would have been even greater, and certainly longer lasting, if others of their general guidelines, such as quality universal public health and education, had been tenaciously pursued" (Kerstenetzky 2017, 25).

The legacy left by the measures adopted during the years 2003 to 2014 was certainly positive, the living conditions of Brazilians evolved significantly. Many have left absolute misery, illiteracy is no longer the rule, life expectancy increased, as well as access to basic health services and welfare and social security systems (Carvalho 2018, chapter 1). However, given the severity of social imbalances that have existed for so long, the advances achieved were not enough to promote a real transformation in the Brazilians lives. The cycle of social investments was too short for the size of the challenges and its depth was contained by a persistent conservative resistance, which prevented the developmental experience from reaching the necessary density and redistributive rhythm and that structural changes to occur (Calixtre and Fagnani 2018, 357). The differences between whites and blacks, men and women, urban and rural workers remain shocking.

It is not just the income that separates people, but the place of birth, the color of the skin, the gender. The graph below illustrates the current inequality reality, affecting people especially due to their racial origin and gender. 
Esta revista forma parte del acervo de la Biblioteca Jurídica Virtual del Instituto de Investigaciones Jurídicas de la UNAM http://www.juridicas.unam.mx

\author{
SOCIAL INDICATORS OF INEQUALITY BY ETHNICITY, \\ GENDER AND PLACE OF RESIDENCE ${ }^{11}$
}

\title{
Desigualdade social no Brasil
}

Veja indicadores sociais por cor, sexo e domicílio

\begin{tabular}{|c|c|c|c|c|}
\hline Etnia & IDHM & $\begin{array}{l}\text { Expectativa } \\
\text { de vida ao } \\
\text { nascer }\end{array}$ & $\begin{array}{l}\text { Pop. com mais } \\
\text { de } 18 \text { anos } \\
\text { com ensino } \\
\text { fundamental } \\
\text { completo }\end{array}$ & $\begin{array}{l}\text { Renda, } \\
\text { em R\$ }\end{array}$ \\
\hline Negros & 0,679 & 73,2 & $47,78 \%$ & 508,90 \\
\hline Brancos & 0,777 & 75,3 & $62,14 \%$ & $1.097,00$ \\
\hline \multicolumn{5}{|l|}{ Sexo* } \\
\hline Mulheres & 0,720 & 77,3 & $56,67 \%$ & $1.059,30$ \\
\hline Homens & 0,719 & 69,8 & $53,04 \%$ & $1.470,73$ \\
\hline \multicolumn{5}{|c|}{$\begin{array}{l}\text { Situação de } \\
\text { domicílio }\end{array}$} \\
\hline Rural & 0,586 & 71,5 & $26,51 \%$ & 312,74 \\
\hline Urbano & 0,750 & 74,6 & $59,72 \%$ & 882,64 \\
\hline
\end{tabular}

\section{G}

Infográfico elaborado em: 09/05/2017

As seen in the compiled data, black people have substantially lower HDI, besides having lower life expectancy, reduced schooling rates and average income less than half that perceived by white people. With regard to women, the biggest differential lies in the average income, much lower than that of men, despite having more years of study. Also remarkable are the large disparities that persist between rural and urban populations.

11 Available in https://g1.globo.com/economia/noticia/desigualdade-diminui-mas-renda-de-ne gros-ainda-e-metade-da-de-brancos-no-brasil-aponta-estudo.ghtml, access in 11 the march the 2020. 
Esta revista forma parte del acervo de la Biblioteca Jurídica Virtual del Instituto de Investigaciones Jurídicas de la UNAM

It is important to take into account that the Minimum Wage in force in 2017, the reference year of the information under analysis, was $R \$$ 937.00 (about $\$ 170$ in current values), which shows how the average income of Brazilians in general, and especially of vulnerable groups, is low. It should be noted, however, that the data on income received relate to the averages. Considering that the income concentration in Brazil is one of the highest in the world, to the point that $10 \%$ of the population holds almost $50 \%$ of the country's income, it is easy to notice how the real incomes of most people are extremely low. For people's majority, Brazil is a very poor country.

At the end of the years 2003-2014, when the global recession hit the country hard, the economic gains made by the poorest quickly receded. At the same time, as of 2015, when the budget deficit led the Federal Government to reverse the expansion of access to rights and social investments, there was a rapid and severe deterioration of living conditions, especially for the poorest. As Laura Carvalho explains (2020, 20-22), from 2015 the Federal Government opted for a pro-cyclical action. Thus, instead of increasing - or at least maintaining - public investment in order to mitigate the loss of income caused by the recession, an agenda was adopted aimed at reducing the budget deficit, at the cost of an even greater downturn in economic activity.

In the last six years, there has been a rapid abandonment of the commitment to the constitutional social project. Since 2015, the path followed by government is that of radical liberalism which, in order to be implemented, requires the dismantling of the model designed in 1988. This happened, for example, through Constitutional Amendment 95/2016, which limited the expansion of spending in social areas; of the Law $13,467 / 2017$, which promoted a broad reform in labor legislation and incorporated several mechanisms to make labor relations more flexible; and of the social security system reform, implemented through Constitutional Amendment 103/2019. All these measures have entailed the restriction of social rights and the number of protected persons, in addition to reducing the role of the State as a social welfare promoter.

The last brazilian governments made an option on the path of constitutionalization of fiscal austerity, which is frankly incompatible with the 1988 project. The scenario drawn is a definite dismantling of the universalist social welfare designed 30 years ago, and as a consequence, it can be ex- 
Esta revista forma parte del acervo de la Biblioteca Jurídica Virtual del Instituto de Investigaciones Jurídicas de la UNAM

pected increased differentiation, social segregation and inequality. As Celia Kerstenetzky warns $(2017,29)$ : "Judging by the reformist hyperactivity of these times, the current bet is on the residualization of social policy: even more deteriorated social services would be sought only by the poor or impoverished, devalued pensions would undergo an assistentialist process, addressing only the same groups, while those groups with higher incomes would seek private solutions (...)".

If the world were still in a phase of experimentation about the possibilities of welfare regimes, such an option would be acceptable. The reality, however, indicates, based on numerous studies, that restrictive models "(...) flow into segregation of well-being and free rein for inequalities such as concentration at the top - just look at what happens, for example, in the United States" (Kerstenetzky 2017, 30). The extreme and persistent inequality present in Brazilian society limits the human evolution of significant portions of the population and restricts the country's development capacity. The transformative project designed in the 1988 Constitution is still necessary, and the option to abandon it is not reasonable.

\section{GONCLUSION}

The National Constituent Assembly functioned as a huge sounding box that gave voice to an intense set of social demands, accumulated and silenced during the previous decades. At that time, inequality was the most relevant theme and, although the capitalist world was immersed in a deep and prolonged economic crisis and dominated by liberalizing and antistate doctrines, the constituents bet on social well-being as an organizational paradigm to be incorporated by the brazilian State.

A broad agenda of social commitments was inscribed in the Constitution, accompanied by different participation mechanisms, aimed at ensuring the protagonism of minority groups, thus breaking the hegemonic logic of a financial elite that has always controlled power. During the constituent process there were resistances, but these ended up being defeated by an unmatched capacity of articulation and expression of different agents. Misery should be tackled, historical inequality fought, exclusion would no longer be the rule for an immense layer of the population. The State would be responsible for a virtuous protagonism, no longer as an authoritarian dominator, but as an inducer of development in action ar- 
Esta revista forma parte del acervo de la Biblioteca Jurídica Virtual del Instituto de Investigaciones Jurídicas de la UNAM

ticulated with society. Finally, Brazil was moving towards an effective social welfare.

More than a normative framework, the Constitution brought a set of commitments and a constant call to social action, of which it was a direct result. This, however, did not remain at the intensity that would be necessary given the size of the problems experienced by brazilians. On the contrary, the years following 1988 were marked by constant movements aimed at reducing the Constitution transformative capacity. The State's economic fragility was used as a pretext to put the debate on social needs in the background and, while the governments sought to stabilize public accounts, the constitutional project was being redesigned.

Since 1988, four cycles can be identified during which the degree of commitment to the Constitution fluctuated:

i) 1988-1994: emptying of social mobilization and constitutional debate, undermined by persistent economic instability;

ii) 1994-2002: economic stabilization and inflationary control associated with liberalism and constitutional reform, within a minimum state project;

iii) 2003-2014: social advances linked to commitments with fiscal conservatism, a project that allowed important gains, but did not dare to break the barriers of exclusion;

iv) 2015 onwards: recession and neoliberal turn, accompanied by a new wave of reforms aimed at reducing the scope of protective constitutional systems.

Today, in Brazil, as in the years that followed the constitutional promulgation, the argument of the State's financial exhaustion is used again as a backdrop to hide the true long-living intentions of deconstructing the social welfare project. Criticisms of protective systems such as that brought by the 1988 Constitution are against facts, especially in a scenario like the current one, in which a persistent economic crisis crushes the poorest classes and a pandemic of global proportions shows clearly to everyone the precariousness of so many people's living conditions.

It is evident that the constitutional project has flaws and inconsistencies, but certainly the Brazilian's financial problems or the social deficiencies still present so broadly cannot be attributed to it. About thirty years ago, the world was going through an equally troubled economic scenario and Brazil bet on the State to correct the directions of a deeply unfair and 
Esta revista forma parte del acervo de la Biblioteca Jurídica Virtual del Instituto de Investigaciones Jurídicas de la UNAM

unequal society. And in the moments when he took on the expected protagonism the results were not bad... Today, injustice and social inequality are problems that should be on everyone's agenda, but, unlike before, the State is leaving the scene and abandoning its social role in favor of fiscal stability, as if they were antagonistic objectives: or to take care of people, or taking care of public accounts. And once again the dreams deposited in the 1988 Constitution give way to the financial elites' interests who appropriate the State. These are shadowy times...

\section{REFERENCES}

Afonso, José Roberto R. 2018. "Desenvolvimento, trabalho e seguro social: volta a Keynes para enfrentar novos desafios". Revista BNDES, vol. 26, núm. 50. Río de Janeiro. https://web.bndes.gov.br/bib/jspui/han dle/1408/16842.

AlbuQuerQue, Marcos Cintra Cavalcanti de. 1987. "Economia brasileira-um nó de contradições". Revista Lua Nova, vol. 3, núm. 3, São Paulo. http://wrere.scielo.br/scielo.php?'script=sci_arttextEpid $=$ S0102-64451987000200015.

ANDRADE, Régis de Castro. 1988. "Pacto democrático, negociação e autoridade. Reflexões sobre a questão da democracia". Revista Lua Nova, vol. 4, núm. 14. São Paulo. http://wrere.scielo.br/scielo.php?'script=sci_artte $x t$ Ëpid=S0102-64451988000100002.

BACHA, Edmar. 1974. "O Economista e o Rei da Belíndia: uma fábula para tecnocratas". Fornal Opinião. São Paulo. https://edisciplinas.usp.br.

BACKes, Ana Luiza, Azevedo, Débora Bithiah de and Araújo, José Cordeiro (orgs). 2009. Audiências Públicas na Assembleia Nacional Constituinte: a sociedade na tribuna. Brasília: Biblioteca Digital da Câmara dos Deputados. http://bd.camara.leg.br.

Bastos, Vânia Lomônaco and Costa, Tânia Moreira da (orgs). 1987. Constituinte: Temas em debate. Caderno CEAC/UnB. Brasília. UnB.

Boschetti, Ivanete. 2006. Seguridade Social e Trabalho. Paradoxos na construção das políticas de previdência e assistência social no Brasil. Brasília. UnB. 
Esta revista forma parte del acervo de la Biblioteca Jurídica Virtual del Instituto de Investigaciones Jurídicas de la UNAM

Bresser-Pereira, Luiz Carlos. 1988. "Os limites da 'abertura' e a sociedade civil”. Fleischer, David (org.). Da Distensão à Abertura. As eleições de 1982. Brasília. UnB.

Bresser-Pereira, Luiz Carlos. 2012. "Prefácio". Kerstenetzky, Celia Lessa. O Estado do Bem-estar Social na Idade da Razão. A reinvenção do Estado social no mundo contemporâneo. Río de Janeiro. Elsevier.

Calixtre, André and Fagnani, Eduardo. 2018. "A política social nos limites do experimento desenvolvimentista (2003-2014)". CARnEIRO, Ricardo, Baltar, Paulo, SARTi, Fernando (orgs). Para Além da Política Econômica. São Paulo. UNESP. https://wrere.eco.unicamp.br/images/arquivos/para-alem-da-politica-economica.pdf.

Carvalho, Laura. 2018. Valsa Brasileira. Do boom ao caos econômico. São Paulo: Todavia.

Carvalho, Laura. 2020. Curto-circuito. O vírus e a volta do Estado. São Paulo. Todavia.

CoelHo, João Gilberto Lucas. 2009. "Processo constituinte, audiências públicas e o nascimento de uma nova ordem". BACKES, Ana Luiza, AzEvedo, Débora Bithiah de, ARAúJo, José Cordeiro (org). Audiências Públicas na Assembleia Nacional Constituinte: a sociedade na tribuna. Brasília. Biblioteca Digital da Câmara dos Deputados. http://bd.camara.leg.br.

Dallari, Dalmo de Abreu. 1998. Ditadura constitucional. Folha de São Paulo. Opinião. São Paulo. http://wrew 1.folha.uol.br/fsp.

EsPing-Andersen, Gosta. 1991. "As Três Economias Políticas do Welfare State". Revista Lua Nova. São Paulo, núm. 24. http://wrere.scielo.br/ scielo.php.script $=$ sci_arttextEpid $=$ S0102-64451991000200006.

FAndiÑo, Pedro y Kerstenetzky, Celia Lessa. 2019. "O paradoxo constitucional brasileiro: direitos sociais sob tributação regressiva". Revista de Economia Política, vol. 39, núm. 2. http://wrere.scielo.br/scielo. php?script $=$ sci_arttextEpid $=$ S0101-31572019000200006.

KerstenetzKy, Celia Lessa. 2012. O Estado do Bem-estar Social na Idade da Razão. A reinvenção do Estado social no mundo contemporâneo. Rio de Janeiro. Elsevier.

Kerstenetzky, Celia Lessa. 2017. "Foi um pássaro, foi um avião? Redistribuição no Brasil no século XXI". Novos Estudos CEBRAP, vol. 36, núm. 2. http://wrerw.scielo.br/scielo.php? script=sci_abstractEpid=S0101330 $02017000200015 \mathcal{E} \operatorname{lng}=p t$ E̊nrm $=i s o$ Ettlng $=p t$. 
Esta revista forma parte del acervo de la Biblioteca Jurídica Virtual del Instituto de Investigaciones Jurídicas de la UNAM

LunARDI, Soraya y Dimoulis, Dimitri. 2013. "A forte e persistente desigualdade social (1988-2011)". VIEIRA, Oscar Vilhena et al. (orgs.). Resiliência Constitucional. Compromisso maximizador, consensualismo politico e desenvolvimento gradual. São Paulo. Direito GV. https://bibliotecadigital.fgv. br/dspace/handle/10438/10959.

Mattos, Fernando Augusto Mansor de y Nascimento, Natassia. 2019. "Aspectos históricos dos efeitos da evolução do salário mínimo, do mercado de trabalho e da estrutura tributária sobre o perfil distributivo brasileiro desde meados do século XX". Tempo Ë Argumento. Revista de história do tempo presente, vol. 11, núm. 27. Universidade do Estado de Santa Catarina, 429-474. http://revistas .udesc.br.

Menezes, Daniel Francisco Nagao. 2014. Economia e mutação Constitucional. Belo Horizonte. Arraes.

MOREIRA, Eduardo. 2020. Economia do desejo. A farsa da tese neoliberal. 3. ed. Rio de Janeiro. Givilização Brasileira.

NASSAR, Paulo André. 2013. "Construção do compromisso maximizador: análise do processo constituinte e das características da Constituição de 1988". VIEIRA, Oscar Vilhena et al. (orgs.). Resiliência Constitucional. Compromisso maximizador, consensualismo político e desenvolvimento gradual. São Paulo. Direito GV. https://bibliotecadigital.fgv.br/dspace/handle/10438/10959

NeRI, Marcelo C. 2019. A Escalada da Desigualdade. Qual foi o impacto da crise sobre a distribuição de renda e pobreza? Río de Janeiro. FGV Social. https:// cps.fgr.br/desigualdade.

NogueIrA, André Magalhães. Centrão. Centro de Pesquisa e Documentação da Fundação Getúlio Vargas http://www.fgv.br/cpdoc/acervo/dicionarios/ verbete-tematico/centrao.

OXFAM. 2018. Uma Economia para os 99\%. Chegou a hora de promovermos uma economia humana que beneficie a todos, não apenas a uns poucos privilegiados. http://wwre.oxfam.org.br.

OXFAM. 2019. Brasil: Direitos Humanos em Tempos de Austeridade. http:// wrwre.oxfam.org.br.

PInTO, Élida Graziane, Afonso, José Roberto y PorTo, Laís Khaled. 2019. "Limites à dívida consolidada e mobiliária da União: um estudo acerca da inconstitucionalidade por omissão na falta de fixação do seu regime jurídico”. ConTi, José Maurício et al. (orgs.). Dívida Pública. São Paulo. Blucher. 
Esta revista forma parte del acervo de la Biblioteca Jurídica Virtual del Instituto de Investigaciones Jurídicas de la UNAM

PIRES, Waldir. 1989. "A social-democracia nas condições do Brasil". JAGUARIBE, Hélio (org). A Proposta Social-democrata. A social-democracia na atualidade europeia, hispano-americana e brasileira. Río de Janeiro. Instituto de Estudos Políticos e Sociais. José Olympo.

SANTOS, Wanderley Guilherme dos. 1986. "O Estado Social da Nação". Dados. Revista de Ciências Sociais. Rio de Janeiro, vol. 29, núm. 3. http:// dados.iesp.uerj.br/artigos/?id=329.

SILVA, José Afonso da. 2013. "Prefácio". Lima, João Alberto de Oliveira, Passos, Edilenice, Nicola, João Rafael (org.). A Gênese do Texto da Constituição de 1988, vol. I. Brasília. Senado Federal. http://wrere.senado.leg.br/ publicacoes/GeneseConstituicao/.

SOUZA JúnIOR, José Geraldo de. 1987. Soberania e direitos: processos sociais novos? Bastos, Vânia Lomônaco; CostA, Tânia Moreira da (org). Constituinte: Temas em debate. Caderno CEAC/UnB. Brasília. UnB.

SOUZA JúnIOR, José Geraldo de. 1987. "Triste do poder que não pode". Bastos, Vânia Lomônaco, Costa, Tânia Moreira da (org). Constituinte: Temas em debate. Caderno GEAG/UnB. Brasília. UnB.

VERSIGNASSI, Alexandre. 2015. Crash. Uma breve história da economia. 2a. ed. São Paulo. LeYa.

VIEIRA, Oscar Vilhena et al. (org.). 2013. Resiliência Constitucional. Compromisso maximizador, consensualismo político e desenvolvimento gradual. São Paulo. Direito GV. https://bibliotecadigital.fgr.br/dspace/handle/10438/10959. 